\begin{tabular}{|c|c|c|}
\hline 7 & Our Nature & $\begin{array}{l}\text { ISSN: 1991-2951 (Print) } \\
\text { ISSN: 2091-2781 (Online) }\end{array}$ \\
\hline 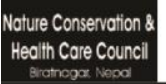 & Journal homepage: http://nepjol.info/index.php/ON & (c) ${ }_{\mathrm{BY}}$ (5) \\
\hline
\end{tabular}

\title{
Relationships between environmental conditions and fish assemblages in the Lohore River of Dailekh, Western Nepal
}

\author{
Sushil Shrestha ${ }^{1}$, Dipak Rajbanshi ${ }^{2}$, Dil Kumar Limbu ${ }^{3}$ and Jash Hang \\ $\operatorname{Limbu}^{4 *}$ \\ ${ }^{I}$ Central Department of Zoology, Tribhuvan University, Kirtipur, Kathmandu Nepal \\ ${ }^{2}$ Department of Zoology, Post Graduate Campus, Tribhuvan University, Biratnagar \\ ${ }^{3}$ Department of Botany, Central Campus of Technology, Tribhuvan University, Hattisar, Dharan, \\ Nepal \\ ${ }^{4}$ Department of Zoology, Central Campus of Technology, Tribhuvan University, Hattisar, Dharan, \\ Nepal \\ *E-mail:limbujash@gmail.com
}

\begin{abstract}
The Lohore River is one of the important riverine ecosystems of Dailekh which support diverse aquatic communities. The present study was carried out to assess the fish diversity status with relation to environmental conditions in both to space and time. The survey was conducted at three different sampling stations in three different seasons. For the fish sampling, two cast nets of different mesh sizes were used, one having large mesh size of $2 \mathrm{~cm}, 6 \mathrm{~m}$ diameter and $6 \mathrm{~kg}$ weight and another having mesh size of $0.5 \mathrm{~cm}, 3 \mathrm{~m}$ diameter and $2 \mathrm{~kg}$ weight. Moreover, drag net and gill net were also used to collect the fish samples. A total of 11 fish species belonging to 2 orders, 3 families and 7 genera. Results from the similarity percentage analysis (SIMPER) suggested that fish species of Puntius gelius, Schizothorax plagiostomus, Tor chelynoides and Schistura sovana were major contributing species each contribute more than $9 \%$. An analysis of similarity (ANOSIM) pointed that fish community structure in the Lohore River differ in spatial scale $(p<0.01)$ but not in temporal scale $(P>0.01)$. Water temperature, dissolved oxygen and water velocity was found as influential factors for fish species distribution.
\end{abstract}

Key words: Diversity, fish, freshwater, Himalaya, Hill-stream, snow-fed

DOI: https://doi.org/10.3126/on.v19.i1.41217

Manuscript details: Received: 09.03.2021 / Accepted: 03.10.2021

Citation: Shrestha, S., D. Rajbanshi, D.K. Limbu and J.H. Limbu 2021. Relationships between environmental conditions and fish assemblages in the Lohore River of Dailekh, Western Nepal. Our Nature 19(1): 18-26. DOI: https://doi.org/10.3126/on.v19.i1.41217

Copyright: (C) Shrestha et al., 2021. Creative Commons Attribution - Non Commercial 4.0 International License.

\section{Introduction}

Both fresh and marine ecosystems harbored almost half of the total number of vertebrates (Gupta, 1988). The Florida Museum of Natural History calculated 27,650 species of extant fishes of which $41 \%$ are freshwater occupying less than $0.01 \%$ of Earth's volume. Over two thirds freshwater fish belongs to single clade Ostriophysi (i.e. minnows, characins, and catfish). In the Indian sub-continent there are more than 2500 species with approximately 930 species exclusively occupied freshwater ecosystem (Jayram, 2010). Fish community structure play an imperative role in keeping the good condition of water in aquatic ecosystem as well as it intensify the articulation of different nutrients and their circulation and recharge in the 


\section{Shrestha, Rajbanshi, Limbu and Limbu / Our Nature | December 2021 | 19 (1): 18-26}

aquatic bodies. Fish community gives signal for the status of freshwater ecosystem since it is tactful to a broad range of stressors (Karr, 1981). The diversity and distribution pattern of fish has been widely related with the environmental factors like dissolved oxygen (DO), free carbon dioxide $\left(\mathrm{CO}_{2}\right), \mathrm{pH}$, alkalinity and more critically with the temperature (Yan et al., 2010; Limbu et al., 2020; Limbu and Prasad, 2020; Prasad et al., 2020). In the context of Nepal, there is rich diversity of freshwater aquatic fauna including fishes and plankton. Moreover, fish diversity of Nepal has been poorly studied or understood relative to other fauna (Shrestha et al., 2009; Limbu et al., 2018; 2021). There is a strong relationship between different water quality parameters with the diversity, distribution and abundance of species. In the shallow and

\section{Materials and Method}

\section{Study area}

The Lohore River is located in Dailekh MidWestern Nepal (Fig. 1). The study was carried out from Dungeshwor to Chupra covering the polluted water some hardy species of fish like catfish and larvivorous fishes were found to be residing and schooling. Similarly, the type of water bottom, bed substrate, depth of water bodies, density of water and temperature along with its velocity played vital role in diversity and distribution patterns of the fish species (Kadye et al., 2008; Li et al., 2012). There has been considerable debate in recent literature as to the relative importance of physical and biological factors in structuring fish assemblages in streams and rivers (Gorman and Karr, 1981). This study aims to determine the fish diversity status with relation to environmental conditions in both to space and time. The findings are expected to enhance knowledge on fish richness in less explored rivers like Lohore River.

length of $19 \mathrm{~km}$. The Lohore River originates from Mahabu lekth on North and finally joins with Karnali River at Tallo Dungeshwor on South. It lies between $28^{\circ} .45^{\prime}$ and $28^{\circ} .45^{\prime}$ North latitude and $81^{\circ} .34^{\prime}$ and $81^{\circ} .41^{\prime}$ 'East Longitude.
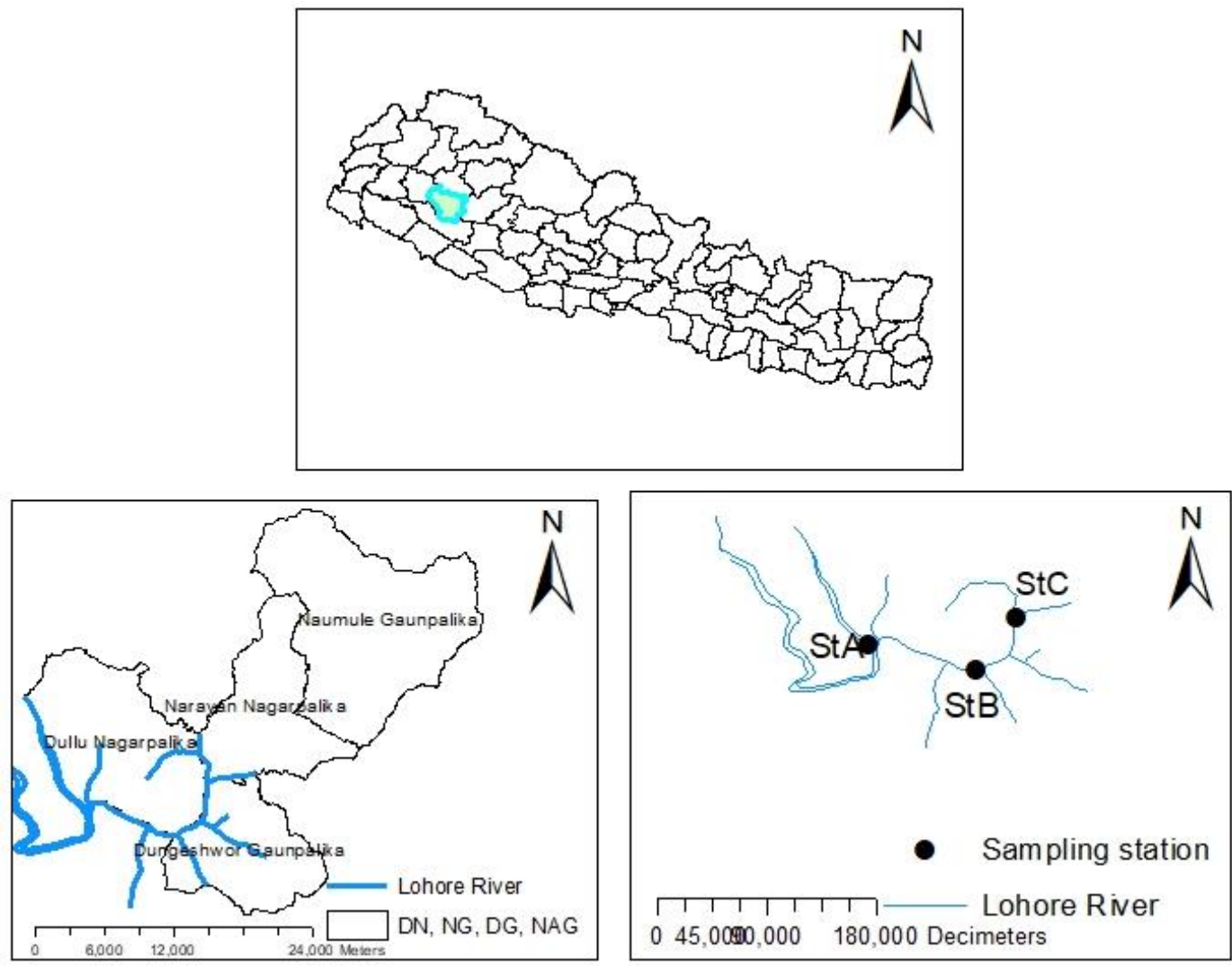

Figure 1. Map of study area showing Lohore River with sampling stations. 


\section{Data Collection, Preservation and Identification}

The fish sampling was done across the three sampling stations. The major gear used for the present research work was cast net of monofilament type made by hemp fiber. Two cast net of different sizes were used, one having large mesh size of 2 $\mathrm{cm}, 6 \mathrm{~m}$ diameter and $6 \mathrm{~kg}$ weight and another having mesh size of $0.5 \mathrm{~cm}, 3 \mathrm{~m}$ diameter and $2 \mathrm{~kg}$ weight. The smaller was used in the upstream having low water volume, while larger was used in downstream having high water volume. Besides, a drag net made from a local mosquito net of mesh size $0.2 \mathrm{~cm}$ was used for collecting small fish species. The collection was done seasonally (autumn, winter and spring, summer) from September 2019 to April 2020. Fishing gears were operated within $500 \mathrm{~m}$ length at each sampling station from 7 am to $1 \mathrm{pm}$. A total of 100 throws were made for cast net and 50 hauls for gill net to catch the fishes. For estimation of abundance of fishes, two removal pass method (Seiber and Le Cren, 1967) was used. Each removal pass includes moving first upstream then downstream within a pre-determined length $(500 \mathrm{~m})$ with equal effort of 30 minutes for each pass at each side of river. The collected fish samples were photographed and were preserved in $10 \%$ formalin solution in plastic jar and brought to Central Department of Zoology (CDZ) lab, Tribhuvan University, Kirtipur, Kathmandu, Nepal for further identification. The collected fishes were identified using standard taxonomic references (Talwar and Jinghram, 1995; Jayram, 2010).

The environmental variables measured in situ during the field visit included: water temperature, dissolved oxygen (DO), free carbon-dioxide $\left(\mathrm{CO}_{2}\right)$ and water velocity. Water temperature $\left({ }^{\circ} \mathrm{C}\right)$ was measured with a digital thermometer (Hanna, HI98501, UK) by placing it in the water at a depth of 1 feet. The DO $(\mathrm{mg} / \mathrm{l})$ was measured by the Winkler titra-metric method, while $\mathrm{pH}$ was measured using a pH meter (HI98107, Hanna Instrument, UK). Free carbon dioxide $\left(\mathrm{CO}_{2}\right)$ was analyzed by titrating water sample against a strong alkali $(\mathrm{NaOH})$ and Phenolphthalein indicator was used in titration. Water velocity was measured by the float method with the help of a stop watch, plastic ball and measuring tape.

\section{Data analysis}

One-way analysis of variance (ANOVA) was used for temperature, $\mathrm{pH}$, dissolved oxygen, hardness and water velocity to calculate the existence of any differences between space and time spectrum. A post-hoc Tukey HSD test was used to test which means were significantly different at a 0.05 level of probability (Spjøtvoll and Stoline, 1973).

Shannon Weiner diversity index (Shannon and Weaver, 1963) considers both the number of species and the distribution of individuals among species. The Shannon-Weiner diversity was calculated by following formula:

$\mathrm{H}=\sum_{i=1}^{S} P i * \log P i$

Where $S$ is the total number of species and $P i$ is the relative cover of $i_{t h}$ of species.

The dominance index (Harper, 1999) was calculated by using following formula:

$\mathrm{D}=\sum_{i}\left(\frac{n i}{n}\right)^{2}$

Where $n_{i}$ is number of individuals of species $i$.

Evenness index (Pieleu, 1966) was determined by the following equation:

$\mathrm{E}=\mathrm{H}^{\prime} / \log \mathrm{S}$

Where, $\mathrm{H}^{\prime}=$ Shannon- Weiner diversity index $\mathrm{S}=$ Total number of species in the sample.

One-way permutational multivariate analysis of variance (perMANOVA) (Clarke, 1993) was used to test the significant difference among the spatial and temporal scales. To visualize the major contributing species both to space and time, similarity percentage (SIMPER) (Clarke, 1993) analysis was performed. Samples by species, sites and environmental variables were analyzed through multivariate analysis tool. Detrended correspondence analysis (DCA) (Hill and Gouch, 1983) was performed to determine whether redundancy correspondence analysis (RDA) or canonical correspondence analysis (CCA) would be the most appropriate model to describe the association between species, sites and environmental variables. The value of axis length and eigen values obtained from DCA suggested that the linear model associated with RDA was more applicable. 
Therefore, a direct multivariate ordination method (Legendre and Legendrem, 1998) based on a linear response of species to environmental gradients was applied.

\section{Results}

Over the one year of monitoring period, 11 fish species were reported in all catch samples. The species comprised 7 genera, 3 families and 2 orders (Table 1). The dominated order Cypriniformes comprised $81.81 \%$ with 9 fish species whereas order Siluriformes comprised $18.18 \%$ with 2 species (Fig. 2). At the family level, the top families that accounted for $81.81 \%$ of the total species counts included Cyprinidae (8), Nemacheilidae (1) and Sisoridae (2) (Table 1). At the species level, $\sim 60 \%$ of catches were dominated by 4 fish species, namely, Tor chelynoides (21.18\%), Puntius gelius (15.27\%), Schizothorax plagiostomus (13.3\%) and Schistura sovana $(9.85 \%)$. But results from the similarity percentage analysis (SIMPER) suggested that fish species of Puntius gelius, Schizothorax plagiostomus, Tor chelynoides and Schistura sovana were major contributing species each contribute more than $9 \%$. An analysis of similarity (ANOSIM) pointed that fish community structure in the Lohore River differ in spatial scale $(p<0.01)$ but not in temporal scale $(P>0.01)$.

Table 1. Fish species collected from Lohore River.

\begin{tabular}{llll}
\hline Order & Family & Code & Species \\
\hline Cypriniformes & Cyprinidae & C1 & Puntius gelius Hamilton, 1822 \\
& & C2 & Puntius chola Hamilton, 1822 \\
& & C3 & Tor chelynoides McClelland, 1839 \\
& & C4 & Schizothorax plagiostomus Day, 1877 \\
& & C5 & Schizothoralchthys labiatus Day, 1877 \\
& & C6 & Garra annandalei Hora, 1921 \\
& & C7 & Garra gotyla Menon, 1964 \\
Siluriformes & C8 & Garra nasuta Hora, 1921 \\
& Nemacheilidae & C9 & Schistura sovana Hamilton, 1822 \\
& Sisoridae & C10 & Glyptothorax pectinopterus Hora, 1923 \\
& & C11 & Pseudechenesis sulcatus Day, 1877 \\
\hline
\end{tabular}

\section{Diversity status}

The value of diversity indices such as Shannon Weiner diversity index $(\mathrm{H})$, Simpson dominance index (d) and evenness index (E) were calculated according to space and time (Fig. 2 and 3). Highest Shannon diversity index 2.29 was found at station C and lowest was found at station A. Higher Shannon Weiner diversity index value was found in Summer (2.28) where low in Autumn (1.72). There was no significant difference $(P>0.05)$ was found in the value of Shannon Weiner diversity index both for time and space. Highest Simpson dominance index was found at station $\mathrm{C}(0.88)$ where low at station $\mathrm{A}$ (0.84). Maximum dominance index value was determined in Summer (0.89) where minimum in Autumn (0.79). No significant difference $(P>0.05)$ was observed among the seasons and stations. Maximum evenness index value was recorded at station B (0.86) and minimum was at station A (0.81). Similarly, highest evenness value was found in Autumn (0.94) where low in Summer (0.85). There was also no significant difference $(P>0.05)$ among the space and time. 
Shrestha, Rajbanshi, Limbu and Limbu / Our Nature | December 2021 | 19 (1): 18-26

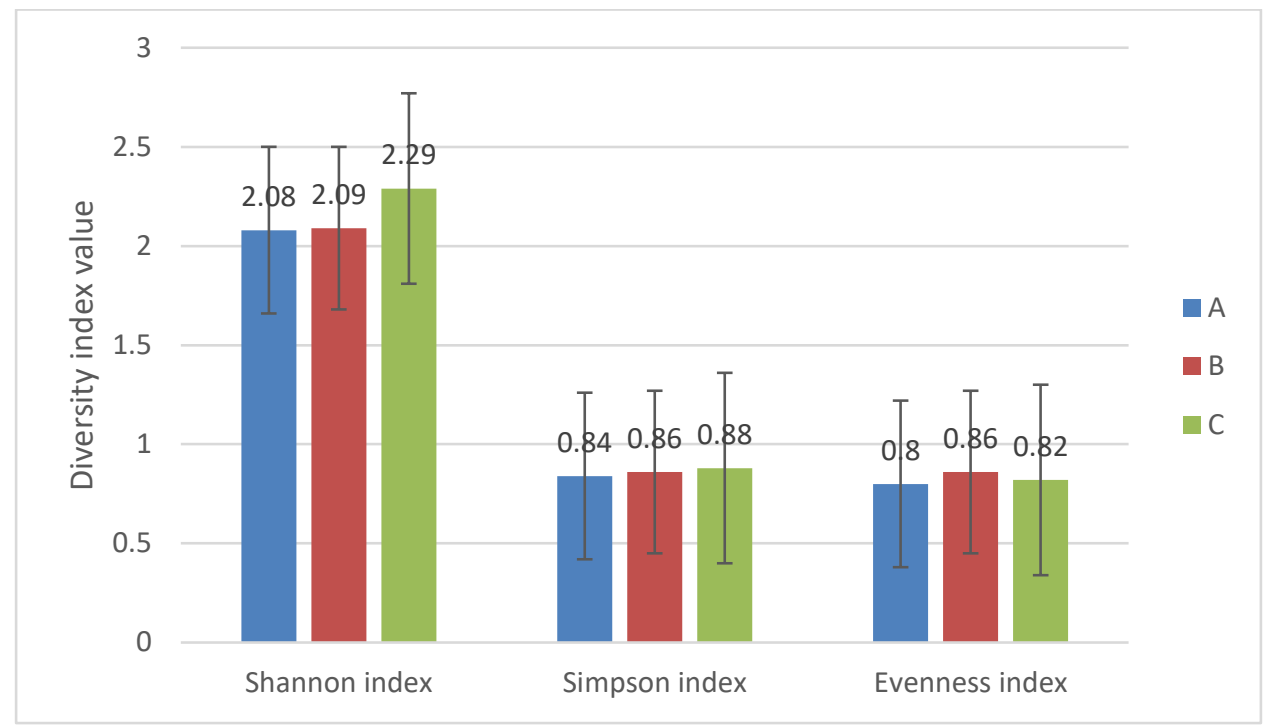

Figure 2. Spatial variation of Shannon, Simpson and evenness index values (A, B, C = station).

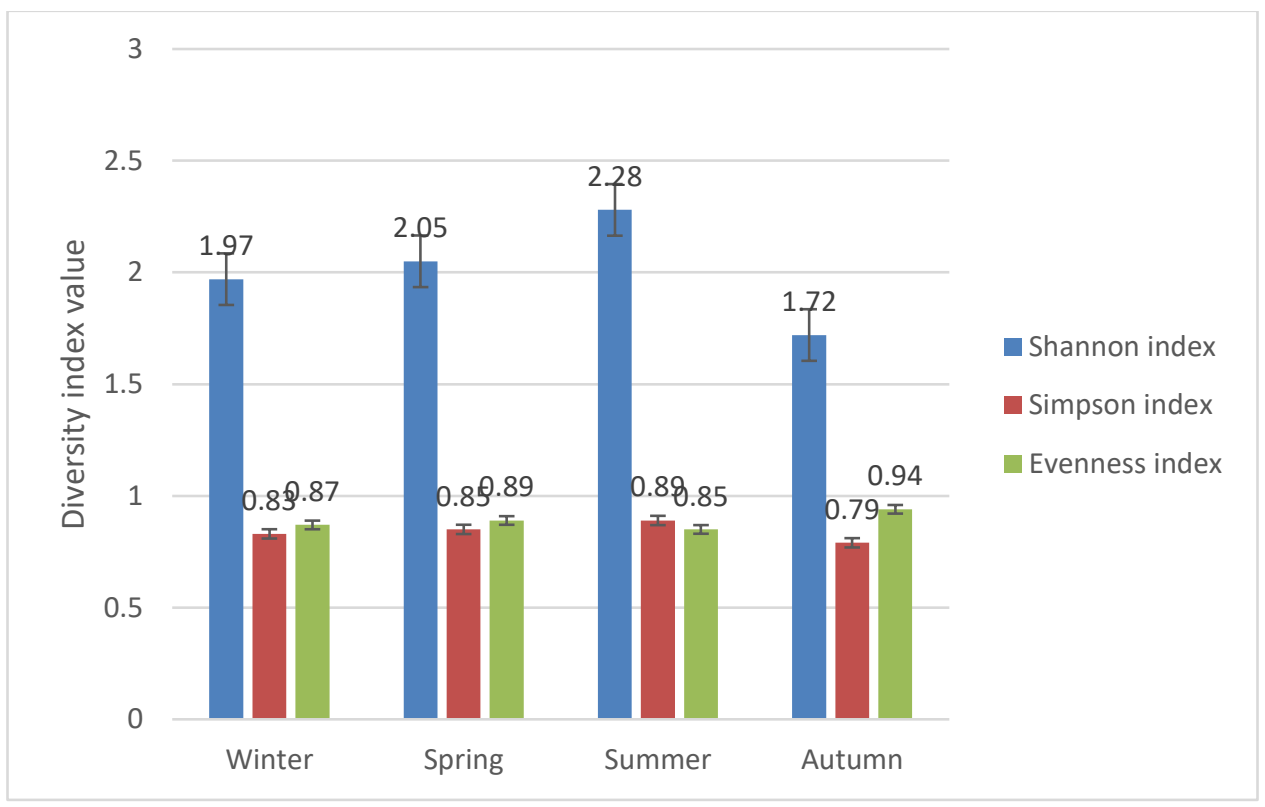

Figure 3. Temporal variation of Shannon, Simpson and evenness index values.

\section{Relationships between environmental conditions and fish community structure}

The first and second axis of the redundancy analysis (RDA) accounted for $37 \%$ of the total variance (25\% on the first axis and $13 \%$ on the second axis). The RDA biplot pointed the relationships between environmental conditions and fish community structure (Fig. 4). The first axis explained water velocity, water temperature, dissolved oxygen, $\mathrm{pH}$ and total hardness whereas second axis showed free carbon-dioxide. Fish species, Glyptothorax pectinopterus (C10), Garra nasuta (C8), Garra annandalei (C6), Pseudechenesis sulcatus (C11), Puntius chola (C2), Schizothoralchthys labiatus (C5), Schistura sovana (C9) and Garra gotyla (C7) are highly associated with dissolved oxygen, water velocity and water temperature but negatively related to free carbon-dioxide $\left(\mathrm{CO}_{2}\right)$. In contrary, single species Puntius gelius (C1) is positively related free carbon-dioxide but negative to 
Shrestha, Rajbanshi, Limbu and Limbu / Our Nature | December 2021 | 19 (1): 18-26

dissolved oxygen, water velocity and water temperature whereas two fish species Tor chelynoides (C3) and Schizothorax plagiostomus
$\mathrm{C} 4$ are related to any variables. Similarly, among the selected variables $\mathrm{pH}$ and total hardness are not related to any variables.

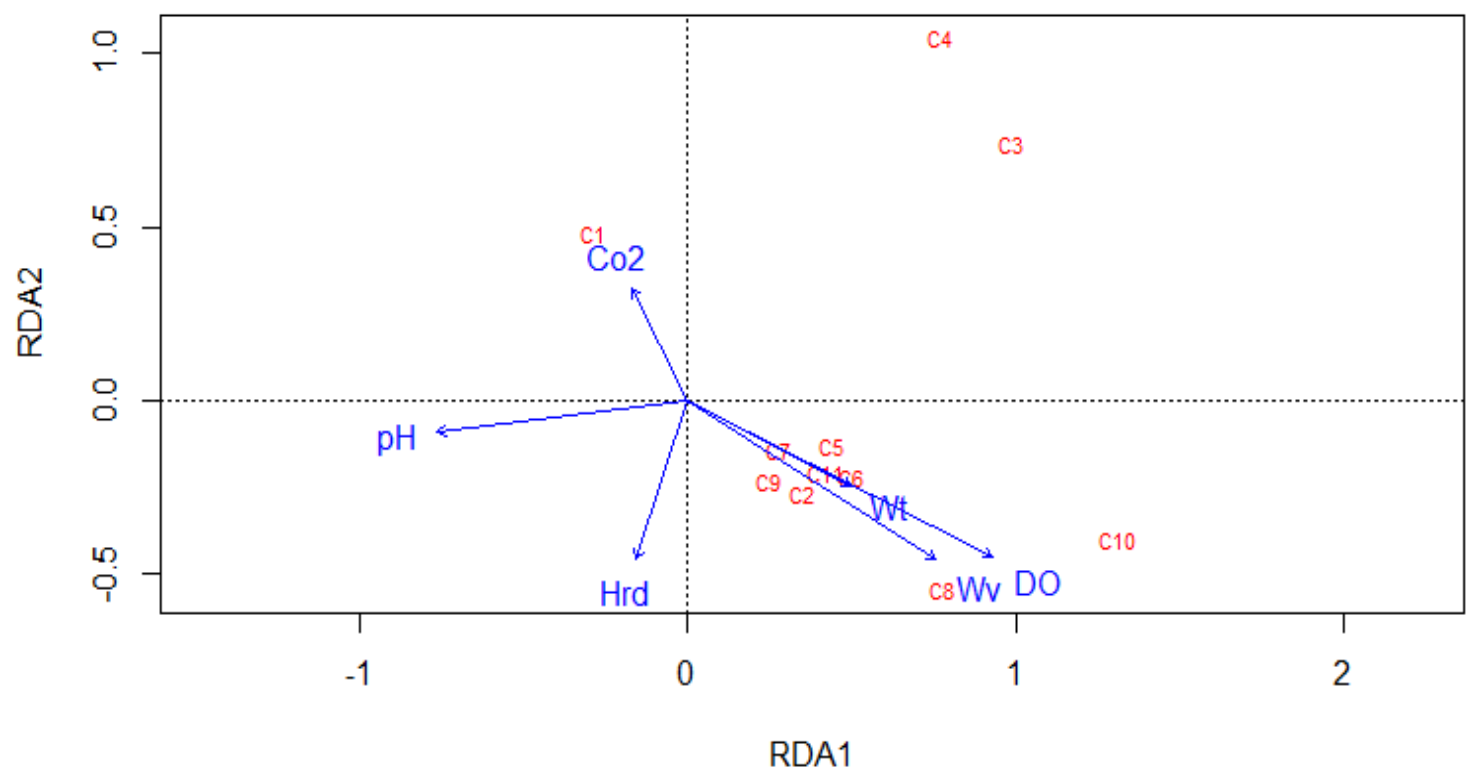

Figure 4. Biplot from redundancy analysis (RDA) for the fish assemblages in the Lohore River $\left(\mathrm{CO}_{2}=\right.$ Carbon-dioxide, $\mathrm{Hrd}=$ Total hardness, $\mathrm{Wt}=$ Water temperature, $\mathrm{Wv}=$ water velocity, $\mathrm{DO}=$ Dissolved oxygen)

\section{Discussion}

A total of 11 fish species were recorded during the study period. In the present study, Cypriniformes and Cyprinidae were the most diverse order and family. This result is consistent with the findings of several previous studies (Mishra and Baniya, 2016; Subba et al., 2017; Limbu et al., 2018, 2019; Limbu and Gupta, 2019; Punam and Limbu, 2019; Limbu et al., 2020; Limbu and Prasad, 2020; Prasad et al., 2020; Limbu et al., 2021a; Limbu et al., 2021b). The majority of the freshwater fish fall under the order Cypriniformes and family Cyprinidae (Nelson, 2016). The analysis of similarity (ANOSIM) showed significance difference in space $(P<0.01)$ but not in time $(P>0.01)$ which is similar to findings of Yan et al. (2010) and Prasad et al. (2020).

A biodiversity index seeks to characterize the diversity of samples by a single number (Magurran, 1988). The biodiversity index values, obtained from the present study, was neither so high according to Shannon-Weiner diversity index, nor showing any differences among the stations and seasons. The reason for showing lower species biodiversity is that fishing gears have high selectivity effect (Keskin and Unsel, 1998). The highest ShannonWeiner diversity index was recorded in Summer, while the minimum was in Autumn. On the other hand, the maximum Shannon diversity value was recorded at station $\mathrm{C}$, and the minimum was at station A. In each case, high Shannon-Weiner diversity index was involved with low individuals, and low diversity was involved with high number of individuals. The main causes of the differences occurring in the biodiversity indexes are the seasonal variations of nutrients at the sea grass beds affecting the coexistence of many fish species (Hossain et al., 2012), the seasonal fish migration (Limbu et al., 2021), the atmospheric air currents and the environmental conditions (Keskin and Unsel, 1998).

The result showed that many physio-chemical parameters like dissolved oxygen (DO), free carbon-dioxide (CO2), temperature, and water velocity were found to be influencing factors for fish diversity and distribution. Besides, other factors like $\mathrm{pH}$ and transparency were significant in trace 


\section{Shrestha, Rajbanshi, Limbu and Limbu / Our Nature | December 2021 | 19 (1): 18-26}

level for fish distribution. The diversity of local species of the river is greatly influenced by temperature as it changes species distribution at short time scales (Fisher et al., 2008). The physicochemical parameters of water like temperature, transparency, velocity, $\mathrm{pH}, \mathrm{DO}, \mathrm{CO} 2$, and hardness play a vital role in abundance and species richness, and these parameters are greatly affected by seasons and elevations (Pokharel et al., 2018).

Different environmental variables influence fish health as well as the diversity and distribution of fishes in water bodies. Among different environmental variables, the temperature and DO are mostly responsible for the observed changes in species diversity and these variables are changes in freshwater assemblages according to seasons and elevation gradients. The relationship between fish and water quality parameters were checked by Canonical correspondence analysis (CCA). In the present study the parameters like DO, water velocity and water temperature were found to be important parameters for shaping the fish assemblage structure of the Lohare River. The dissolved oxygen (Limbu and Gupta, 2018; Limbu et al., 2019) and water temperature (Kadye et al., 2008) have been mentioned as important factors for shaping the fish community structure. Pokharel et al. (2018) observed that the most important environmental variables were conductivity, water depth, free carbon dioxide, $\mathrm{pH}$, and $\mathrm{DO}$ in the Seti Gandaki river basin. The fish assemblage structures are mainly correlated with free carbon-dioxide, water discharge, and stream size in North Tiaoxi River China (Koel and Peterka, 2003).

\section{Acknowledgements}

We would like to thank Prof. Dr. Tej Bahadur Thapa for providing us to conduct this research work. We are highly indebted to Mr. Hira Singh Badi for fish sampling collection during the whole study period. We are very thankful to Shree Vijaya Higher Secondary School Dullu, Dailekh for providing Lab for water quality analysis to assist our work.

\section{References}

Chaudhary, S., J.H. Limbu, S. Subba, J.K. Gurung, N. Pandey, and D.K. Singh 2020. Fish assemblage structure and environmental correlates in Nepal's West Rapti River. Our Nature 18(1): 28-37. https://doi.org/10.3126/on.v18i1.34239

Koel, T.M. and J.J. Peterka 2003. Stream fish communities and environmental correlates in the Red River of the North, Minnesota and North Dakota. Environmental Biology of Fishes 67: 137-155.

Clarke, K.R. 1993. Non-parametric multivariate analyses of changes in community structure. Australian Journal of Ecology 18: 117-143. https://doi.org/10.1111/j.14429993.1993.tb00438.x

Fisher, B., Turner, K. and M. Zylstra 2008. Ecosystem services and economic theory: Integration for policy relevant research. Ecological Applications 18: 2050-2067. http://dx.doi.org/10.1890/07-1537

Gupta, S.P. 1988. Advanced Practical Statistic. S. Chand Publication, New Delhi, India.

Hill, M.O. and H.G. Gauch 1980. Detrended correspondence analysis: an improved ordination technique, Vegetatio 42: 47-58.

Hossain, M.S., N.G. Das, S. Sarker and M.Z. Rahaman 2012. Fish diversity and habitat relationship with Environmental vriables at Meghna river estuary, Bangladesh. Egyptian Journal of Aquatic Research 38: 213-226. https://doi.org/10.1016/j.ejar.2012.12.006

Jayaram, K.C. 2010. The freshwater fishes of Indian region. Narendra Publishing House, Delhi, India, 614.

Kadye, W.T., C.H.D. Magadza, N.A.G. Moyo and S. Kativu 2008. Stream fish assemblages in relation to environmental factors on a montane plateau. Environmental Biology of Fishes 83: 417-428. https://doi.org/10.1007/s10641-0089364-4

Karr, J.R. 1981. Assessment of Biotic Integrity Using Fish Communities. Fisheries 6: 21-27. https://doi.org/10.1577/1548-8446

Keskin, C. and N. Unsal 1998. The Fish Fauna of Gokceada Island, NE Aegean Sea. Turkey. Italian Journal of Zoology 65:299-302. https://doi.org/10.1080/11250009809386836 
Legendre, P. and L. Legendre 1998. Numerical Ecology. Second Edition. Elsevier, Amsterdam, Netherlands. 853 pp.

Li, J.H., L.L. Huang, L.M. Zou, Y. Kano, T. Sato and T. Yahara 2012. Spatial and temporal variation of fish assemblages and their associations to habitat variables in a mountain stream of north Tiaoxi River, China. Environmental Biology of Fishes 93: 403-417. https://doi.org/10.1007/s10641-011$9928-6$

Limbu, J.H. and A. Prasad 2020. Environmental variables and fisheries diversity of the Nuwa River, Panchthar, Nepal. Scientific World. 13: 69-74. https://doi.org/10.3126/sw.v13i13.30542

Limbu, J.H., B. Bhurtel, A. Adhikari, G.C. Punam, M. Maharjan and S. Sunuwar 2020. Fish community structure and environmental correlates in Nepal's Andhi Khola. Borneo Journal of Resources Science and Technology. 10(2):

85-92.

https://doi.org/10.33736/bjrst.2510.2020

Limbu, J.H., G.S. Acharya and O.M. Shrestha 2018. A brief report on ichthyofaunal diversity of Dewmai Khola of Ilam district, Nepal. Journal of Natural History Museum 30: 312-317. https://doi.org/10.3126/jnhm.v30i0.27607

Limbu, J.H., J.K. Gurung, S. Subba, N. Khadka, A. Adhikari and C.B. Baniya 2021b. An Impact Assessment of Betani Irrigation Dam on Fish Diversity of Damak Municipality, Jhapa, Nepal. Egyptian Journal of Aquatic Biology and Fisheries 25(2):

163-175.

https://dx.doi.org/10.21608/ejabf.2021.1613 63

Limbu, J.H., S. Subba, J.K. Gurung, J. Tumbahangfe and B.R. Subba 2021a. Correlation of fish assemblages with habitat and environmental variables in the Phewa Khola Stream of Mangsebung Rural Municipality, Ilam, Nepal. Journal of Animal Diversity $\quad 3(1): \quad 27-36$. http://dx.doi.org/10.52547/JAD.2021.3.1.5

Magurran, A.E. 1988. Ecological Diversity and its Measurement. Princeton University Press, Princeton.
Mishra, A. R. and C.B. Baniya 2016. Ichthyofaunal diversity and physico-chemical factors of Melamchi River, Sindhupalchok, Nepal. Journal of Institute of Science and Technology 21(1): $10-18$. https://doi.org/10.3126/jist.v21i1.16031

Pielou, E.C. 1966. The measurement of diversity in different types of biological collections. Journal of Theoretical Biology 13: 131-144. https://doi.org/10.1016/0022-5193(66)90013-0

Pokharel, K.K., B.B. Khadga, C.M. Trilok, and B.B. Chitra 2018. Correlations between fish assemblage structure and environmental variables of the Seti Gandaki River Basin, Nepal. Journal of Freshwater Ecology 33(1): 31-43.

https://doi.org/10.1080/02705060.2017.139917 0

Prasad, A., A. Shrestha, J.H. Limbu and D. Swar 2020. Spatial and temporal variation of fish assemblage structure in Seti Gandaki River, Tanahu, Nepal. Borneo Journal of Resources Science and Technology 10(2): 93-104.

https://doi.org/10.33736/bjrst.2048.2020

Punam, G.C. and J.H. Limbu 2019. Spatio-temporal variation of fish assemblages in Babai River of Danag district, Province No. 5, Nepal. Our Nature 17(1): 14-25. https://doi.org/10.3126/on.v17i1. 33988

Seber, G. and E.L. Cren 1967. Estimating Population Parameters from Catches Large Relative to the Population. Journal of Animal Ecology 36(3): $631-$ https://doi.org/10.2307/2818

Shannon, C. E. and Wiener, W. (1949). The mathematical theory of communication. Urbana, Uiversity of Illinois Press, pp: 177.

Shrestha, J., D.M. Singh and T.B. Saund 2009. Fish diversity of Tamor River and its major tributaries of eastern Himalayan region of Nepal. Nepal Journal of Science and Technology 10(1): 219-223. https://doi.org/10.3126/njst.v10i0.2964

Spjøtvoll, E. and M.R. Stoline 1973. An extension of the T-Method of multiple comparison to include the cases with unequal sample sizes. Journal of the American Statistical Association 68(344):

975-

978. 
https://doi.org/10.1080/01621459.1973.1048 1458

Subba, B.R., Pokharel, N. \& Pandey, M.R. 2017. Ichthyofaunal diversity of Morang district, Nepal. Our Nature 15(1): 55-67. https://doi.org/10.3126/on.v15i1-2.18794

Talwar, P.K. and A.G. Jhingram 1991. Inland fisheries of India and adjacent countries. Volume I and II. New Delhi, India, Oxford and IBH Publishing Co.
Yan, Y.H.E., C.H.U. Shan, X. Ling, J.I.A. Xiuying, T. Anju, A.O. Juan and C. Yifeng 2010. Spatial and temporal variation of fish assemblages in a subtropical small stream of the Huangshan Mountain. Current Zoology 56(6): 670-677. https://doi.org/10.1093/czoolo/56.6.670

Yu, S.L. and T.W. Lee 2002. Habitat preference of the stream fish, Sinogastromyzon puliensis. Zoological Studies 41: 183-187. 